\title{
Field Activism Becomes Click Activism: A Concept Review of Old Social Movements and New Social Movements Become Online Social Movements
}

\author{
Ahmad Ismail $^{1}$, Hardiyanti Munsi ${ }^{2}$ \\ \{ahmadismailguntur@gmail.com ${ }^{1}$, hardiyantimunsi@gmail.com $\left.{ }^{2}\right\}$ \\ Departement of Anthropology, Hasanuddin University \\ Jl. Perintis Kemerdekaan KM 10, Makassar, Indonesia
}

\begin{abstract}
This article aims to review the concept of social movement based on literature study and field research I have done. Social Movement has been a phenomenon in society in the last decade. The definition of social movements continues to be modified according to the development of society. Starting from the old social movements in the era of the $80 \mathrm{~s}$ to $90 \mathrm{~s}$, the new social movements in the era of the $2000 \mathrm{~s}$, then became an online social movement in the era of 2010s.
\end{abstract}

Keywords: Social movement, Online activism, Click activism

\section{Introduction}

Social movements in Indonesia lately are massive [1] [2]). Based on some research results that we found about social movements, most researchers discussed social movements or resistance carried out in the 1980s to 1990s have not adopted internet technology. Like social movements which lead to peasant movements and agrarian resistance characterized by class struggle [3] [4], the 1998 student reform movement in Indonesia [5] which was later defined as an old social movement [2][6].

Then the New Social Movement which was defined by Singh [6] about the value and form of the movement has shifted from the Social Movement to the New Social Movement which has become social phenomena of the last decade [2]. However, in the current digital era, many social movements are carried out by adopting internet technology especially utilizing social media - Twitter, Instagram, YouTube, Facebook, and blogs - in conducting social movements. The phenomena have not been widely studied so that it becomes interesting to study.

Referring to the research conducted by Faisal [7] about the Greenpeace online activist movement, mass mobilization carried out by the Greenpeace online activist movement is merely symbolic resistance such as petitions and lettering to policymakers rather than giving real or direct opposition in society. It is the same with Nugroho [8] research on the birth of what he called "one-click activism", which also returned "click activism" in question "... Don't think people just press a like button on Facebook, they already feel able to 'change the world', with millions of people doing the same thing. Even though the realization of these activities was only carried out by a handful of people. This is what is feared in civil activism through 
social media in Indonesia. The emerging of a "one-click movement", or "one-click activism" will be in vain without real realization.

This article aims to review the concept of social movements. The journey of this concept continues to experience modifications under the development and phenomena of developing social movements. Starting from old social movements, social movements, to the new ones which were later modified into online social movements.

\section{Research Method}

The method used is the study of literature to discuss the framework of the development of the concept of social movements from the old social movements into the new social movements that have different variations. At the same time, it also shows how strong the impact of the social movement changes.

\section{Result and Discussion}

\subsection{Old Social Movement and New Social Movement}

Social movements are often seen as a collective action to fight against the state in order to fight for the rights of civil society. According to Sudjatmiko [2] social movements are defined as: "a form of collective action with a clear conflictual orientation towards certain social and political opponents, carried out in the context of a close cross-institutional network context by actors who are bound by a sense of solidarity and collective identity that exceeds the forms in coalitions and joint campaigns". The definition is not much different from what we encountered in the sociological literature on social movements, there is also another definition, namely: "social movements are described as the most collective attempts to promote change in a society or a group" [9]. Both of these definitions are not much different from what is expressed by Useem \& Useem [10], social movements as collective actions of organizations, which are forced to make social changes. Axel [11] went more detailed, defining social movements as an organization's effort to make changes in the distribution of any socially valuable things.

From the explanation of the concept of social movements above, it gives an overview of how social movements emerged and worked in carrying out the resistance to the state in the fight for their class, but if the social movements above are seen in the current context, there are many collective movements but not carried out by conducting a "hard" resistance in the sense of taking to the streets and conducting a demonstration.

Based on the explanation above and labeling social movements carried out without the characteristics of class struggle, Singh [6] then divides the concept of social movements into two, namely "old social movements" and "new social movements". Both of these views are not much different about the forms of movement which are conceptualized as "old social movements" and "new social movements". The old social movement was more about bringing the ideological discourses that chanted anti-capitalism, class revolution, and class struggle. Whereas at present, the new social movement expresses itself with rich forms such as anti-racism, anti-nuclear, disarmament, feminism, environmentalism, regionalism, and 
ethnicity, freedom of civil society and issues concerning personal freedom and peace. The new social movement, essentially, is a development of the theory of social movements that existed before. This view is based in Western Europe as Laclau \& Mouffe [12] consider new social movements as alternative models of "stagnation" or "bottlenecks" from the Marxist approach to social movements.

Singh [6] states that the paradigm of the new social movement rests on two main claims: first, new social movements are transitional products from the industrial economy to postindustrial. Second, new social movements are for and different from the Social Movement in the industrial era. If the traditional movement usually emphasizes economic-material goals as well as the labor movement, the new social movements tend to avoid these objectives and set non-economic-material goals.

In the new social movement, there is a slogan that reads "There are many alternatives" [13]. New social movements are present as an alternative to principles, strategies, actions and ideological choices from the views of traditional Marxist theories which are more focused on the problem of class struggle. The new social movement was a separate movement from the previous social movements which were colored by the traditional class of the labor movement. The basic debate is about goals, ideology, strategy, tactics, and participants. The old social movements tend to be thick with the class dimension (Marxian) which is divided into the dichotomy of the bourgeoisie and the proletariat; move on around economic issues/economic re-distribution that are closely related to times where the dynamics of the economy of western countries entered a period of industrialization and thick with the aim of changing the system (overthrowing power) radically/revolutionary. Also according to Sudjatmiko [2], old social movements and new social movements are not differentiated based on the time of the movement, but based on what is the activist fighting for. A movement does not have to start from 'old' then to 'new', and vice versa.

From what happened in the case of the ouster of president Husni Mubarok in Egypt, the case of the anti-wall street movement in the United States, and the case of Prita Mulyasari and Bibit Candra, all of these movements were carried out by adopting internet technology that was so rapidly spreading. The movement is called an "online social movement" that is a social movement combining information technology, namely the internet -Twitter, Instagram, YouTube, Facebook, and blogs- in carrying out their movements. Therefore, the phenomenon of civil society adopting the internet in carrying out social movements is an interesting phenomenon.

\subsection{Online Social Movement: Reality or Illusion?}

This article uses the premise that the types of old social movements and new social movements that adopt the internet can be seen as an "online social movement". The ideology and values that it has are different from others, and provide their own identity in an online movement. How the organization of movements, value-building, practicing and building the views of the actors -that is the right way- and strengthen the social movements.

The Social Movement can also be understood as a community. The community is a clear entity but this term is a term that is highly debated in various fields of science such as anthropology, sociology, and communication, but society is one of the focal points of anthropological investigation. A community or a group in a society has a culture that embodies a rule in that society, a common interest, limited membership, affective bonds, shared values, behavior and interaction based on obligations as the important elements. 
Years before the advent of the internet and the effects of globalization today, the value of affective relationships among members of community groups seems more important to society than the actuality of physical location. Globalization and trans-nationalism continue to show us that social ties, responsibilities, and obligations can cross national boundaries with the internet [14]. Advances in technology have affected communication with exponential increases in quality, speed, and ease of access that can be used to bind members, create a convergence of opportunities and needs [15].

Many opinions about how the internet eliminates the boundaries of space and time make one virtual world transcend physical boundaries [16]. Bromberg proposes that this geographic decoupling of the core role in defining society has opened up discussion space for us to think the internet as a new space for the community. This also affects the anthropology field method [16].

If the internet has become a new space for the community, then how are affective relationships between group members formed? How do actions on the internet make this connection? As an interactive place, the internet facilitates the movement of information, money, and commodities -that are shared, traded, exchanged and sold-, borrowed images, and symbols - that is repackaged- and crossing national and ethnic boundaries [17]. It is an expression of the new world, sharing personal joy and tragedy, debates about the purpose of life, and the ideology of how the world must be formed. It impacts how we understand social capital and its role in social ties in society, but also impacts on the importance of physical locality in building social capital and social bonds that create society.

\section{Conclusion}

The social movements carried out on the internet are not merely click activism, but social movements on the internet can exceed beyond. With the requirement that they have the context of the movement with the real world, social movements on the internet do not escape from the 'real' offline context so that the nuances of the movement built have validity or synchronization between online and offline.

The Social Movement is not only done with social media alone, but collaboration and a combination of "real" and "virtual" spaces have also provided context and validation in carrying out social movements. Organizing is done through social media applications, used as their infrastructure in building communication among fellow volunteers.

The social movements carried out by adopting internet technology have provided a new concept of movement which we call "online social movements". Although referred to as the keyword 'online', this movement is not only done in the internet space, but the offline context of real space is also a part of online social movements to provide context, validation, and attachment to participation in carrying out social movements

\section{References}

[1] Ismail, A., Munsi, H., and A. Hans.: "Online Social Movement: Adopsi Teknologi Informasi dalam Melakukan Gerakan Sosial di Indonesia," ETNOSIA J. Etnogr. Indones (2019)

[2] Sujadmiko.: "Gerakan Sosial: Wahana Civil Society bagi Demokratisasi," D. 
Triwibowo, Ed. Pustaka LP3ES Indonesia (2006)

[3] Scoot, J.: Senjatanya Orang-Orang Kalah. Jakarta: Yayasan Obor Indonesia (2000)

[4] Moore, D.S.: "Marxism, Culture, and Political Ecology: Environmental struggles in Zimbabwe's Eastern Highlands," in Liberation ecologies : environment, development, social movements (1996)

[5] Prasisko, Y. G.: "Gerakan Sosial Baru Indonesia: Reformasi 1998 dan Proses Demokratisasi Indonesia,” J. Pemikir. Sosiol (2016)

[6] Singh, R.: Gerakan Sosial Baru. Yogjakarta: Penerbit Resist Book (2010)

[7] Faisal, M.: "Dari Anarchic Cyber Space menjadi Transnational Public Sphere. Membaca Relasi antara Cyberᄀ space fan Civil Society di Era Postmodern (Studi kasus: Greenpeace Online Activist)," Glob. J. Polit. Int (2007)

[8] Nugroho, Y.: @ksi Warga: Kolaborasi, demokrasi partisipatoris dan kebebasan informasi - Memetakan aktivisme sipil kontemporer dan penggunaan media sosial di Indonesia. Makassar: Manchester dan Jakarta: MIOIR dan HIVOS (2011)

[9] Borgotta, E. F., and Borgotta, M.: Encyclopedia of Sociology (1992)

[10] Useem, B., and Useem, M.: "Government Legitimacy and Political Stability," Soc. Forces (1979)

[11] Axel, B. K.: "The Context of Diaspora," Cult. Anthropol. Vol. 19, no. 1, pp. 26-60 (2004)

[12] Laclau, E., and Mouffe, C.: Hegemony and Socialist Strategy (1985)

[13] Pulungan A., and Abimanyu, R.: Bukan Sekedar Anti Globalisasi. Jakarta: IGJ dan WALHI (2005)

[14] Bernal, V.:“Eritrea on-line: Diaspora, cyberspace, and the public sphere,” Am. Ethnol., (2005)

[15] Howard, P. N. and Jones, S. Society Online: The Internet in Context. Thousand Oaks. Sage Publications (2004)

[16] Bromberg, H.: "Are MUDs Communities? Identity, Belonging and Consciousness in Virtual Worlds," R. SHIELDS, Ed. SAGE Publications London pp. 143-152 (1996)

[17] Barber, B. R.: "Jihad vs. McWorld," Nation (2002) 